REPRINTED FROM THE TRANSACTIONS OF THE BUCHAN FIELD CLUB, 1902.

\title{
ZOOPHYTES:
}

WITH

\section{Special Reference to the Buchan Coast.}

\author{
BY \\ IV. J. ( A I R D.
}

PETERHEAT:

P. SCROGIE, "BUCHAN (IBSERVER" PRINTING WORKS.

1903. 


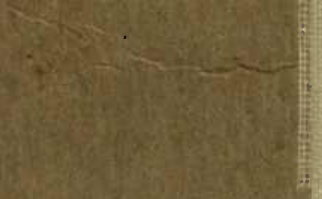




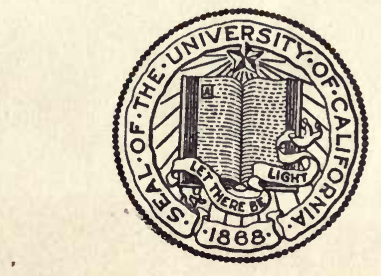

THE LIBRARY OF THE UNIVERSITY OF CALIFORNIA

PRESENTED BY

PROF. CHARLES A. KOFOID AND MRS. PRUDENCE W. KOFOID 



\section{ZOOPHY'TES}

WITH SPECIAL REFERENCE TO THE BUCHAN COAST.

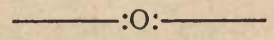

The natural productions to which our attention is to be directed to-night were called zoophytes, it is probable at a time when it was thought by many that they were a connecting link betivixt the animal and vegetable kingdoms; that though it could no longer be denied that they contained animals, yet they were indebted for their growth to an inherent principle of vegetation. The name (animal-plant), though no longer appropriate in this sense, may still be retained as suitable for some of them at least, as having the outward appearance of sea plaiits, but being in reality formed by the !ittle polypes inhabiting their numerous tubes or cells.

Long had they been regarded as within the domain of the botanist. He laid claim to them on various grounds : they often had the external appearance of little shrubs ; they did not, like animals, move from place to place, but remained permanently in the same situation, attached to other objects by fibres much resembling roots of sea plants. Some, from their hard and stony nature, were disposed to place them in the mineral kingdom, alleging that they either were crystallizations formed from calcareous sediment or by some natural incrustations of seaweeds.

Imperato, a Neapolitan, seems to have been the first to state, as the result of his own observations, that corals and madrepores were the work of the living animals who dwelt in them. What reception his publication met with from the naturalists of that day (I60I) I have not been able to learn. Though this work was illustrated by figures, a second edition did not appear till 1672, when the author, I doubt not, had passed away from the land of the living. Even then it seems to have been little read, for when Peysonnel, more than half a century afterwards, communicated the same discoveries to the Academy of Sciences in Paris, they deemed 
it quite new to them, and they appear to have treated the discoverer with scorn as a fanciful dreamer or as a presuming upstart who wished to be wiser than his neighbours.

This treatment of Peysonnel was probably due to the fact that, some time before this, Count Marsigli, an Italian, had written on the subject, and, though he had described the animals he had seen in the corals, he had represented them as the flowers of the corals. $\Lambda$ wordy warfare was carried on for a long time; but, in I74I, the tide fairly turned in favour of Peysonnel's theory, chiefly owing to the research work done by Trembley and Bernard de Jussieu. In I 752, Peysonnel sent a treatise on coral and other marine productions, the result of his own observations for thirty years, to the Royal Society of London. Dr Parsons, a naturalist of some reputation and of great influence in the Royal Society, undertook to refute the statements made.by Peysonnel, and for a time seems to have carried all before him. Parsons considered the animals in the corals as mere accidental settlers, totally inadequate to carry out the great works ascribed to them.

About the same time Henry Baker discharged his last arrow in defence of the mineral theory. In using the microscope he had doubtless observed the beautiful and regular crystallizations which salts, earths, and metals assume, and he stoutly argued that the seeming sea plants were nothing more than crystallizations.

But all the members of the Royal Society were not satisfied. John Ellis, a London merchant, from seeing the polypes in some of our British zoophytes caught a convincing glimpse of the true state of the matter, and prosecuted the study with such ardent zeal that in 1755 he published a work entitled: "An Essay towards a Natural History of Corallines and other Marine productions of the same kind commonly found on the coasts of Great Britain and Ireland." This was the standard English text-book till about 1838 .

Though the doctrine taught by Ellis was the same that had been maintained by Peysonnel, Trembley, and latterly by Réaumur, he so fully illustrated that matter that he may be said to have established its truth, effecting a revolution in the opinions of the generality of scientific men. He showed in those zoophytes of a compound nature, that though a single animal inhabited each cell, yet they were united "by a tender thready line to the fleshy part that occupies the middle of the whole coralline; that the polypes were organically connected with the cells, and could not remove from them; and that that which seemed a plant 
was the covering, whether horny or calcareous, of the hydra, and was as much an animal structure as the nails of a man, the horns of a bullock, or the shell of a tortoise."

This theory has since been so universally adopted that it is not necessary we should trace the history of Zoophytology any further. Let it suffice therefore, if I say that the works published by Allman, Johnston, and Hincks, are the standard works of to-day.

Now-a-days we divide zoophytes into two classes, hydrozoa and polyzoa. Roughly we may distinguish them thus-the hairy-like formations on plants are hydrozoa, in deeper water they take the form of divarf trees ; and the limy incrusting cellular structures found both on plants and stones are polyzoa. To-night we shall confine our attention chiefly to hydrozoa, for I think it better to do one branch of it fairly minutely and so.get a thorough grasp of the subject, and which with a little application of general principles can be made to extend to polyzoa also, than to tackle both branches and so, for want of time, be made to skim the work and leave you only at the threshold of their beautiful mansions.

Now, how are we to obtain our hydrozoa or hydroids as they are sometimes called? In the first place they can be obtained from microscopical dealers at two shillings per packet. These, to my idea, are unsatisfactory, for they are dry, the polypes shrunk into their cells and so unseen. There is nothing like the real live article for imparting a thorough-going interest in this subject. And you have ample ground for searching here on the rocks and in the pools. A stout pair of boots, a glass jar, which must be thoroughly clean, and a walking stick-preferably one with a crook cr handle rather than a knob-are all the requirements necessary for out-door work. Suppose we go down to the shore just now - in imagination - at low tide, till we are close down at the edge of the water. First we swill our bottles, and then three-parts fill with water--mind you don't do it from a pool, or you will get a disappointment when you go home. I did só many times till I learned wisdom. Now look at that tangle (laminaria digitata) pull it over towards you. Ah! I thought so, it has hairs on its tip or broad end. Share it out amongst the others-it is the commonest of all-ohelia geniculata. Cut the frond, do not tear off the hydroids. Now look at the root end. Some times we get little white hairs $1 / 4$ of an inch longsertularia ruoosa. Now, try that other weed with all the bulbs on it strung like a line of buoys on a fishermen's net-I mean the olive- 
coloured weed fucus nodosus. On it tco are hairs, take a share and pop them into your bottle, for you have sertularia pumila. Hullo! there's a hermit crab in a big whelk shell-catch him. Oh, you say, the shell is prickly like a hedgehog, only the prickles are not so long. Good man! keep him - crab and all into your bottle, quick, for you have got one of the simplest and prettiest sights you have ever seen-hydractinia echinata. Let's look at your bottle-just look at all the lovely white hydra you have there-each complete in itself, and yet not complete save altogether. Now, I think we have enough for a start. Before we go just put that little piece of red weed ptilota plumosa with its coral-like incrustation into your bottle also. It is a polyzoa-membranipora membranacea. It - the empty cells-makes a lovely slide for the microscope when mounted on a dark ground, and lighted from above.

Now, let's keep together and we will talk of these on the homeward journey. The first one we got on the tangle obelia geniculata-is the common type of its class. The stalk rises from the stolon (root you may call it) and goes up by joints like a piece of bamboo, bent at every joint out of the straight. From the joint rises a stalk of 6 or 7 rings, and on the top is a bell-shaped cup, with a smooth edge. Inside the cup is your hydra-looking creature. On examination you will find it has tentacles, and a central portion or mouth. If you cast it over in your mind you have seen this form of polype before-true, very much enlarged - the sea anemone.

The sertularia rugosa also arises from a stolon, is likewise zigzag, but the cups are very much wrinkled and have no stalks, i.e., the cups are sessile. The same sort of polype is inside. Sertularia pumila is another of this family and differs from the former by having no wrinkles on the cup, and the cups are sunk into the stalk and come out in pairs, one on each side.

Hydractinia echinata has a stolon, but every here and there the stolon rises up in horny points to give protection to the animal which has no stalk to protect it. If it had been a little later in the season you would have found clear jelly-like swellings on the first three. From these issue miniature jelly-fish or medusoids, which swim about freely, and about August or September next settle on some likely spot and change back into hydroids. Thus in the sea as well as on the land we have an alternation of species.

But the reproductive organ on hydractinia echinata is a modified polype, and not a specialised organ as in the others. 
The polyzoa we have has polypes of the same nature, but the habitation is different-very. Here each cell is laid side by side with its neighbour to which it is attached, and numerous pores like those on a thimble, permit of the entrance of water to keep the animal alive when the storm forbids it to thrust forth its tender head.

But now we have got home,- - the microscope is out and a watch glass is clean. Snip off with a scissors a small piece of the weed, place it in a watch glass with some water. Under an inch power in a minute or so you will observe the polypes come forth. If you look closely you will find that the polypes are busily engaged catching animalcules, and withdrawing into the cups or calycles as they are called, in the same manner as a hydra viridis shuts up when it has made a capture. You will note also that down the centre of the stalk is a darker portion. Put on a higher power and you will find it moving as the polyps extend or contract. This is commonly called the body mass.

I know of no means whereby these can be kept alive for any considerable length of time. I have, by carefully changing the ivater twice a day from the sea, kept obelia geniculata alive for 3 or 4 months, but in the end they died. It they die you must remove them at once from the water and change it, as, like sheep, they have a strong propensity in this dying business to follow their leader.

Many beautiful specimens are not to be had on shore and must be dredged from the sea bottom. If you are acquainted with a trawl skipper, ask him to bring you some of the small trees he gets, or some of the long clear tubes with the red knobs at the end. Or if you know a fisherman ask him to give you all the spider crabs he gets-one spider crab I examined in August, 1902, had I4 different specimens on his back,--some zoophytes, some weeds, some sponges, some worms, etc. It would be also advisable to give him a large sweetie bottle (you can get one for $6 \mathrm{~d}$ ), and ask him to put all the rubbish he gets into it, i.e., all the "bonnie sea flo'ers" as he chooses to call them, and you will get some lovely specimens. You must visit him daily, as the specimens he gets to-day will be dead to-morrow. You should give your trawl skipper a couple of bottles.

Now how are we to deal with them for future use? It is no use mounting the specimens with the polypes inside. To make the slide complete the polypes must be fully extended. The method I adopt and have suggested to others is to take a pipette full of spirit of wine and when the polypes are fully extended, which I see through the microscope, 
I fill my watch glass and poor "Mr Polype" has departed where the wicked cease from troubling. I leave him a minute or so, then take him out of his milky fluid and drop him into a phial of pure methylated spirit. After a minute in spirit of wine I put them in a $4 \%$ solution of formalin. Thus I treat them all. In the case of the hermit crab I get a convenient dish and put shell and all into the water. The polypes in this case are much larger and can be seen by the naked eye. When a good many are extended I dose the whole with spirit. Mr Crab struggles, but the polypes are stiff at once. I pick off the larger specimens with a forceps and add them to the phial. Be sure you put no weeds in the phial. They must be removed after the first dosing with spirit.

I think it is alway's better to stain your specimen by using some aniline dye, say borax carmine. After soaking for a couple of minutes or more according to the strength of your solution, place in an acid spirit, say $75 \%$ spirit, $2 \% \mathrm{HCl}$. This will take the colour out, but do not reduce it too much, as you will lose some colour yet before you are done. Then put it in $90 \%$ alcohol-mythelated spirit will do-and from that in a mixture of creasote and turpentine (half and half), then into pure turpentine. From this to your slide, and mount in balsam. Be careful your turpentine is pure-the commercial turpentine is of no use-for, if bad, it will cause you endless bother and vexation; and even when finished, your slide will disappoint you, as water bubbles get in, and, by their refraction, make close examination with a high power impossible.

If you do not want your specimens for immediate mounting it is advisable to work them off into turpentine, when if properly corked they will keep for any length of time. Some try to keep them in spirit of wine, but I find the body substance deteriorates, and gaps occur in its substance. The polypes too become fragile, and the least shake sometimes plays the mischief with them.

The same results of mounting might have been attained by working from $90 \%$ alcohol to absolute alcohol, and then clove oil and balsam, but I find it is more expensive.

To obtain the second species of the generation-the medusoids-I employ a tow net. It is composed of a hoop, 6 feet in circumference, and a conical net of fine strong muslin, at the end of which I place a zinc can with a rounded lip. I generally use it about half-tide, as I am a lazy man. I pull out in a boat till I get into the tide and drop anchor. Then I fill my can to make sure the net will sink, and lower away-the tide carrying it down and away from the boat. Occasionally I hold on 
to it to make sure it is going down taut, and pay out line equal to three times the depth I want to be in. For deep dredging I have to add weights to the front of the net, but in no case do I allow it to touch the bottom. After being out about half-an-hour I haul it in, pour the liquid contents of the can into a clear jar, add a little more water if the haul has been good, and get ashore. You have always a rare haul, but of the many things we will confine ourselves to two kinds, viz., the jelly fishless than the head of a pin, they could easily go through the eye of a fine needle-and the harp-shaped creatures which are the larval form of our friend membranipora. I add formalin to the jar sufficient to make a $4 \%$ solution. They quickly die off and sink to the bottom. The clear liquid is decanted, and the grounds, you may call them, are put into a small bottle. Thence I take them as required-stain with an aniline dye in water, mount in glycerine jelly, and seal down the glass with gold size. If you should over-stain clear by adding water.

But come, let us get on. Let us grow 6 or 12 months older with respect to our subject. By that time, if we have been fortunate, we should have a fairly good collection, and be able to distinguish most of the common species found around our coasts.

And what shall be the contents of the cabinet? Before answering this question, we must consider the opportunities of the collector. If he can devote day after day to it all the year round, his collection, if he be fortunate, should be large and exhaustive, to describe which would take more time than we have at our disposal. But if our collector can only devote part of a day, or even only Saturday afternoons, his collection would at the end of a year be by no means insignificant. I will take it therefore that, since all of us, or most at any rate, must devote days and nights to provide the necessaries of life, our collection will not be by any means complete. But to describe even this collection, to.night would yield to to-morrow and to-morrow, and so we will confine our attention to the chief types only.

Obelia geniculata is sure to form part of the collection, as it is the commonest of all our local hydroids. You are doubtless acquainted with the fresh water hydra. You know that it reproduces its species by budding, and casting free the bud after a time. But if instead of casting off the young hydra it should lengthen out, and in turn bud, and this should lengthen out and bud, and so on, and so on, then you would have a colony of hydra on a main stalk. This method of growth is also seen in plants. First cotyledons, then the stalk lengthens out and puts forth 
buds, which may develop into leaves or branches. This similarity of growth was one of the chief reasons which enabled botanists to claim it as a plant. And as if this was not sufficient, it also developed the sucker at the end of the hydra into long filaments, which spread out in various ways, and by a secretion enabled it to attach itself to some anchorage. These filaments were naturally termed the root. If you observe the marine plants you will observe that the root in no case seeks a downward course. Something hard, something to which they can attach themselves, is all that they require, for the marine plants do not to a great extent, if indeed to any, depend on their roots to supply nourishment.

The stem is zig-zag, sometimes sparingly branched, jcinted at each of the flexures, and thickened immediately below them, so as to form a series of projections or rests on alternate sides. From these projections, by a connecting part of 4 to 6 rings, arise the calycles. The calycles or cups are bell-shaped, smooth-edged, and transparent. These calycles or cups carry the polypes or hydranths, as they are called. The hydranths are solely nutritive persons. Their function is to catch, swallow, and digest prey. Many times I have watched them when they were feeding. Every animalcule that came within range of the tentacles was speedily encircled, drawn within the calycle, and swallowed. I have chopped seaweed as small as I could, and tried to drop it among the tentacles. It was swiftly encircled by the tentacles and immediately rejected. This I cannot account for, unless I did not mince it fine enough. I do not think I contaminated the food; for, to test it thoroughly, I once soaked my hands in sea water for about half-an-hour before attempting to mince the weed. It made no difference. Mr Hydranth would have none of it. This, then, drives me to the conclusion that they are carnivorous. Those of you who have kept and watched actinia feeding must have been struck by the eagerness displayed in engulfing a worm or piece of butcher meat, and the reluctancy to eat sea weeds. With the weeds, I fancy the sea anemone says, "Well, I'll take it if you have nothing else to offer, but I really do prefer a worm."

Now, let us consider the internal organisation of the hydranth. As I said, it has a circlet of tentacles. Unlike actinia or hydra, the tentacles are solid, and cannot be lengthened or contracted by water. In the centre of the tentacles lies the mouth, which leads into the hypostome. The food here is to a great extent deprived of the surrounding water, and is then passed through a sort of gullet into the gastravascular cavity or stomach. The digested parts are passed through a very narrow 



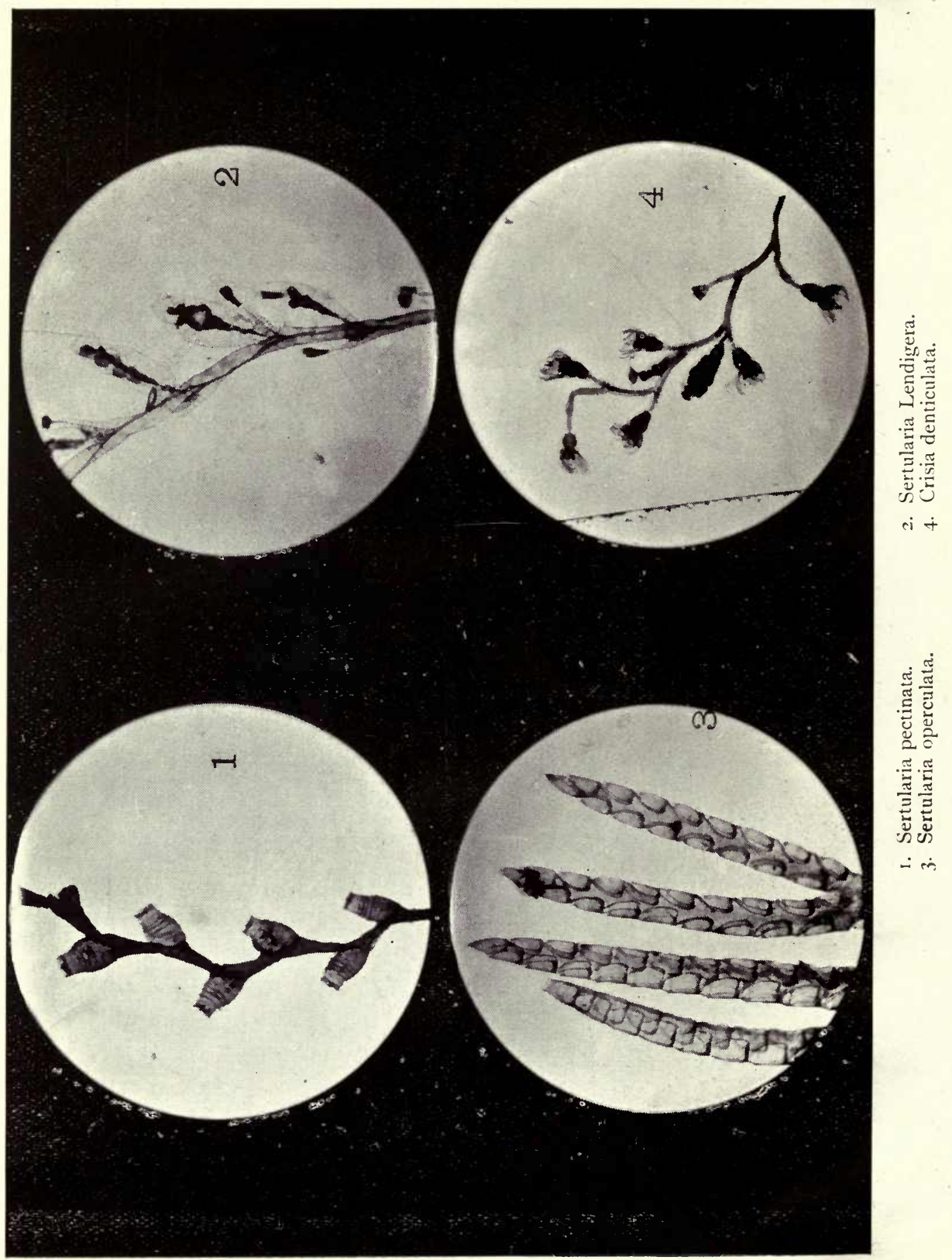



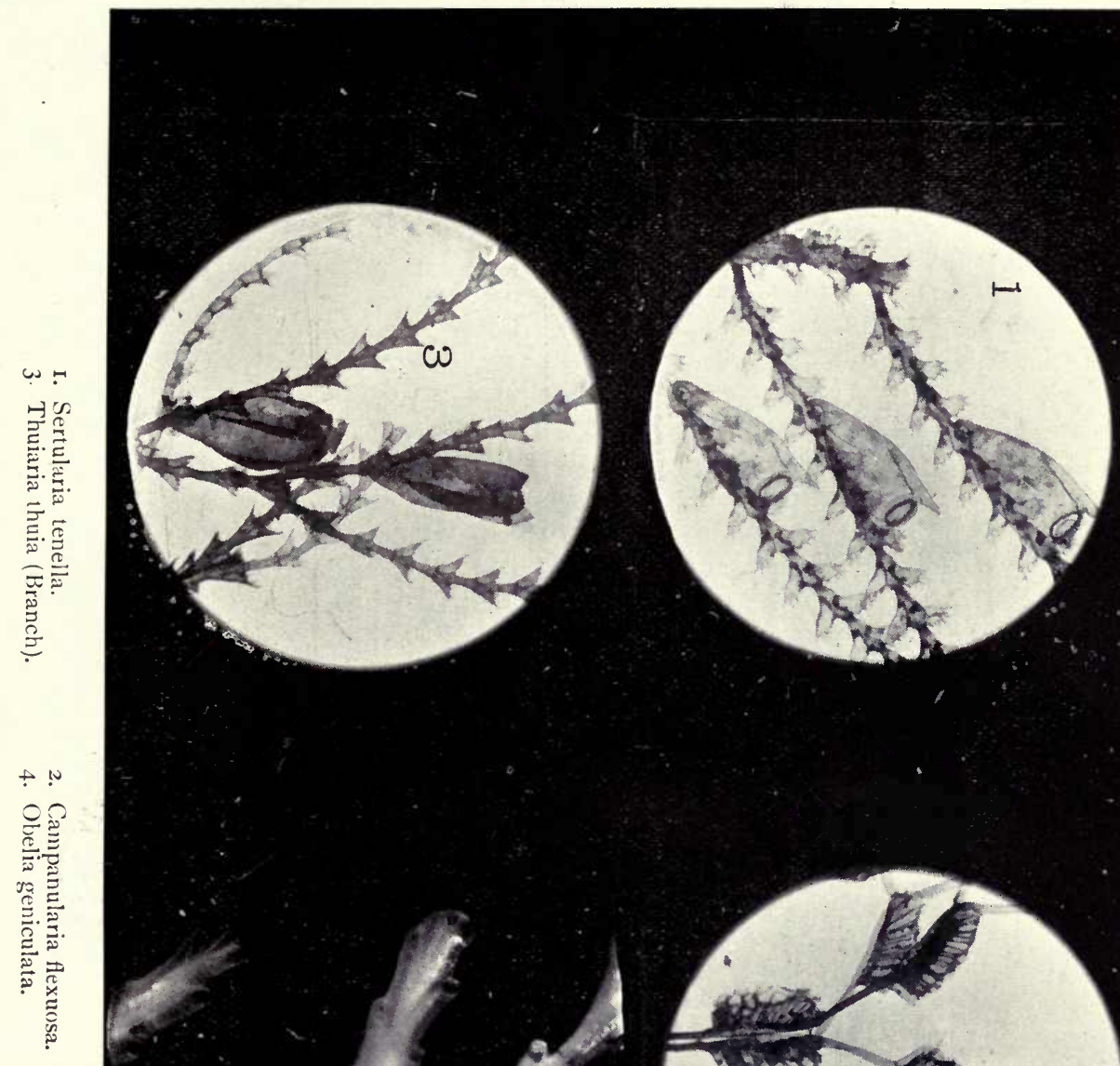

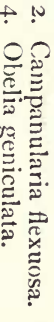



channel, through the rings, and into the general body cavity. The undesirable paris are cast forth by the animal turning itself inside out.

A bout this passing of the digested food into the general body cavity, which runs right from end to end, have we not here a true system of socialism? Each hydranth works for the whole, and the whole for it. How very different such a system is from that practised by man!

Betiveen the hydranth and the main stalk arises in the month of November or so a little bud, which develops into a most elegant form resembling a Greek vase or urn. It is elongate, and tapers off gradually from the flattened top to the base where it becomes very slender. It usually lies at right angles to the hydranth. This beautiful urn is called a gonotheca. This gonotheca contains nothing more or less than a degeiserate hydriform person without mouth or tentacles. Last winter I kept some obelia and strange to say, as I kept them well supplied with water containing animalculae, several of the calycles degenerated into gonothecae, so that there was the uncommon sight of two gonothecae close together at the same projection. I kept them till the month of June, and then as I went on holidays I was unable to look after them. When I returned I found that they had been considered dead and had been cast away. I would have liked to have known what effect the two gonothecae would have, and if any of you come across such a specimen, I trust you will not forget me, but give me a share. Inside the gonothecae are large members of gonophores which develop and escape through an opening at the top of the gonothecae as medusoids. These medusoids are miniature jelly fish. But though I say jelly fish, pray do not mistake me, for they are not the jelly fish you are accustomed to see in the water. These you can take and handle easily if you have gloves on, or are careless whether they sting you or not, but the jelly fish that comes from hydroids can easily, when full grown, pass through the eye of a needle. But though so small they are complete. Each one has its complement of tentacles, its water vascular system, its mouth or manubrium, its reproductive organs. Some biologists even go the length of saying they have equivalents to our eyes and ears.

On the four radial canals of our medusoid are the reproductive organs called gonads. Here comes a break in the life history. How can this jelly fish turn back into a hydroid? No one, so far as I know, has observed such a stage. I have a theory of my own that since they resemble jelly fish so very much in some stages, why not in all? I have not observed this stage, and my theories do not always prove correct, so 
I would suggest that some of you try to fathom the depths of the mystery, and give the world of science the benefit of your researches. But if for the present you allow me to assume this stage, then the cycle of generations is complete. As in the case of the butterfly we have various stages, viz., egg, catterpillar, chrysallis, imago; so do we have an alternation of species, hydroid, medusoid, and our missing planula.

Sometimes obelia geniculata is coloured red, the colour being due to a very minute alga which covers the surface with a net-work of chain-like vegetation. O. geniculata is a phosphorescent species, and the sudden illumination of a forest of it on some sombre laminarian frond is a truly beautiful spectacle. If it is agitated in the dark a bluish light runs along each stem, flashing fitfully from point to point as each hydranth lights up its little lamp.

I have gone fully into the life history of obelia geniculata because all the others are the same, or nearly so, save for the mere outward appearance.

Now, let us take the next group in which the calycles are sessile, i.e., have no stalks with rings which permit of movement. These sessile cups take many forms. By far the commonest one in pools is sertularia pumila. The cups are in pairs set one on each side of the main axis. Sometimes branches are developed. You will note here the peculiar V shape the cells take. If you notice you still find the body contents running the whole length of the axis, and a very tiny thread linking on each hydranth. Save for a slight variation in the number of the tentacles the anatomy of the hydranth is the same as that of $O$. geniculata.

You will observe, too, that the stalk is marked off by nodes, deeply cut into the axis, so much so that one. wonders why it does not break off when the swirl of some fish tail strikes it. The gonothecae are of two kinds, the irregularly ovate one with the tubular rim is the female, whilst the male is more slender and regularly ovate.

But another variety sertularia tenella has the calycles alternately situated. The calycles are outside the stalk although attached closely to it. The calycles are very much wrinkled, and if the wrinkled calycles had been sunk into the stalk instead of placed upon it, our specimen would be sertularia rugosa. The life history and anatomy does not vary from the specimens already considered, but I would direct your attention to the relatively large size of the calycles. Judging from the specimens which have gone before, this fellow ought to have them only half the size of what they are. 
I never fail to get these when I want them by merely searching the roots of the big tangles that have been cast up on the beach. Of course they are dead then, but if you are fortunate to get down to the beach a two or three hours before a coming storm, you sometimes get them alive, when slicing off the stalk of the tangle and merely keeping the root in a jar of water, you may be successful in getting them home alive. After a storm, of course, they are dead, for what can stand the pounding on the beach for several hours. Much harder and bigger specimens of flotsam get ground down into mince meat, so how can you expect such a tiny, fragile creature to stand a test you yourself shrirk from in fear and trembling?

Now as we go further into this branch we find that the specimens have come from deeper depths, and the collector has either trawled for them or is indebted for them to some kind fisherman.

Plumularia similis is a most delicate, fragile specimen. You will notice the stalks, calycles, hydranths, are all relatively small. The calycles are all upon the top side of the branch, and spaced out fairly well.

But hydrallmania falcata has the calycles packed closely together in a sort of double row, i.e., they are slightly placed to each side, and where one ends and another begins, on the opposite side is the main part of the calycle of the alternate row.

In aglaophenia the calycles are of two kinds, the ordinary large fellow, and several small ones at the top and bottom which are generally termed guard cells. A sort of clasp binds the main calycles to the stem, so that it is sessile, and the little guard cells are stalked, but so slightly that their movement is limited.

Let us next consider shortly Antennularia. There are two kinds got here-one having boughs, Ramosa; the other straight as a palm tree, Antennina. The branching in this case is distinctive. Formerly we have had bilatral symmetry as regards branching, but here it takes the form of circular and not lateral symmetry. The branches are arranged in whorls, like equisetum, of five branches at a time, and are so arranged that the one set fits exactly in between the vacant spaces of the one immediately below it. The Antennularia grow to a considerable length-sometimes a foot long.

The branches are very delicate and easily broken off when dry. I have often got specimens but never a live one. They live at a considerable depth (30-40 fathoms), and I fancy I must account for my non-suc- 
cess in procuring live specimens by the fact that the pressure at the surface is vastly different from what they have been accustomed to, and the sudden change is too great for the poor little dears. But I have seen drawings of them, so I am still hopeful that perseverance may yet win the day.

It is scarcely possible to imagine that our imaginary collection can be without a specimen of the Bottle-brush if our collector has been receiving all the useless stuff from a fisherman's line. How very appropriate is the name it has - Bottle-brush! Instantly our mind flies to the idea of the twisted wire and the bristles all at one end, and such is a very good resemblance to our next-Thiuaria Thuia as it is called. It is of a dull brown colour, and by no means prepossessing. It attaches its stolon to a shell commonly a mussel, but a stone is also equally serviceable. I have never seen it attached to a weed, but minute algae frequently incrust it when it is dead. It reaches a length commonly of about 6 or 7 inches, though specimens of a foot lorig may sometimes be got. In almost every case the branches are about two-thirds up the stalk, so that the top third is the only part which carries the polypes. On some of the specimens on the table if you examine the stalk with a pocket lens you will find the scars where the older branches ciropped off. Is not this another point for the botanist? Does he not find leaf scars and branch scars where there have been droppings off? Aye, but he has to account for the peculiar shape of the branches here. No leaves only branches, and these fitted half through with cells. He cannot get off by saying these cells correspond to the stomata of plants, for what is the use of stomata to a plant sixty fathoms down beneath the flowing tide? If he thinks so he must find out the guard cells, he must account for the polypes in the cells, and what I think will be more difficult, he must explain away the difficulty of the polypes being joined to the central body mass.

The gonothecae or seed capsules arise on the top side of the branch. If you examine one of the specimens with a pocket lens you will find the gonothecae as minute translucent balls. They are several times the size of a single cell, and as is customary each has a lid or operculum to permit of the exit of the young medusoids.

This leads us to the dwarf trees. For our illustration I have chosen Eudendrium rameum-a very common form. As you see, it resembles a tree very much, which I suppose partly or wholly accounts for the Greek derivation of its name. It never grows very high in this district, 
four to five inches being the average height. In colour when fresh it resembles a dark chestnut brown. The trunk is thick and coarse, composed of many agglutinated tubes. The principal branches are compound below, but running out to a single tube towards the extremity. It is very much ramified. The polypes are vase-shaped, of a reddish colour, and bear 24 tentacles.

Sir John Dalyell writes of this as follows:- "This is a splendid animal production - one of the most singular, beautiful, and interesting among the boundless works of nature. Sometimes it resembles an aged tree, blighted amidst the war of the elements, or withered by the deep corrosions of time; sometimes it resembles a vigorous flowering shrub in miniature, rising with a dark brown stem, and diverging with numerous boughs, branches or twigs, terminating in so many hydrae, wherein red and yellow intermixed afford a fine contrast to the whole."

I think his enthusiasm is perfectly justifiable, for it is one of the prettiest sights I know to see one of these shrubs in the full glory of robust health.

It is widely scattered over the North Sea, and I would urge those of you who have never examined one to search diligently for it. It will well repay you. It is found in deep water (30 fathoms or so). I have never got it in tidal waters. Like Thuiaria it is quite careless whether it attaches itself to a shell or a stone.

Following Eudendrium we may take Tubularia Indivisa. The polypes are somewhat similar to those of Eudendrium, but it has no branches. The tubes in which it lives are almost transparent and the little red head of the polype can easily be seen with the naked eye.

Tubularia Indivisa presents some new features. It has no branches but large clusters may be got. Unlike the preceding types it carries a double row of tentacles, the outer and lower being much the larger. The reproductive organs have their origin between the two sets of tentacles, and extend beyond the lower row. These organs consist of a thin thready line, on which are grouped in pairs the capsules containing the medusoids.

Now we have finished some of our types of the stalked hydroids, and descending now from our first specimen obelia geniculata we may take hydractinia echinuta. What a horrible length of name for a thing the size of a pin head! Really I think somebody should start and recast all these names for us. I am sorry to have to use these names, but as I know of no others I am unable to simplify them. 
If you remember when we were down at the shore, somebody grabbed a hermit crab incautiously, and slightly pricked his fingers. These prickles are the defensive persons of hydractinia. In this species we have what may be termed a division of labour. The large polypes with the proboscis and the long white tentacles are those which are primarily charged with looking after the commissary department Their sole function is to eat-eat-eat, and nothing but eat. Of course the digested food passes as usual into the general body cavity and thus the whole is nourished.

Others take upon themselves the duty of playing the part of watchmen. The head of the polype is rounded off very small, and the tentacles are aborted. They cannot eat, but they have developed the art of scenting danger from afar, and instantly the whole colony take fright. Several times this summer I tried experiments on this hydroid, which may be summed up thus. You may tickle the gormandiser pretty freely and he does not mind you, but if you touch a sensitive person ever so slightly the whole colony shuts up at once--in the twinkling of an eyt.

There are other persons yet-each polype you must remember is called a person-which greatly resembles the sensitive person. These feel also, but not to the same high degree. Near the head of these are found numerous sporosacs in big clusters. Several medusoids emerge from each sporosac. I have wondered why so many medusoids should be developed, and only recently have I come to a finding satisfactory to myself. Hydractinia always-mark this-always chooses the univalve shell inhabited by the hermit crab. The other species we have considered seemed careless about their anchorage, any place would do so long as it is safe. But not so hydractinia. It will only take the shell inhabited by this crab or none. There are many suitable shells in the sea, but if $\mathrm{Mr}$ Crab does not choose to live inside, it will not take up its quarters there either. This seems to show a sort of reasoning powerat least a discriminating power of the free planula stage of the animal, just the same as the ordinary white butterfly selects the cabbage on which to deposit its eggs. You can easily find other examples-expressed in different ways - of this discriminating power, both in animal and vegetable kingdoms, and doubtless too, you can give or manufacture reasons why these should be so.

So, too, I will hazard a guess why the medusoid stage of hydractinia selects this inhabited shell. If it settled on the rocks, or on the weeds, 
the number of animalculae that came within its reach would be relatively small, for it does not grow to anything like the length of thuiaria, antennularia, or obelia, and I fancy it requires about as much food. Hence it selects a moving house-one that can move considerable distances. Now if you watch it whilst the crab is moving you will find that the polypes are all on the hunt, ready to seize any unwary prey. It gets many a knock as $\mathrm{Mr}$ Crab journeys over rocks and weeds, but the sensitive person is always on the outlook for dangers ahead, and if perchance Mr Crab should fall from a height, the spikes of chitin are ready to bear up the shell and save the colony from being hurt. Most of the nutritive polypes you will observe are on the under side--another discrimination, for when $\mathrm{Mr}$ Crab is feeding small bits of his food are constantly being dropped and carried along on the tide. These they readily seize and digest, and so get an abundance of food. It is strange that when $\mathrm{Mr}$ Crab quits his shell for another larger one, the hydractinia mourns his departure very much. He must take it very much to heart, for he promptly and speedily dies-a few days and he has gone the way of many more. He has yet to learn the lesson taught him by his cousin (I won't say of what degree) the sea-anemone, adamsia, for it settles on the shell the hermit crab occupies, and as $\mathrm{Mr}$ Crab grows so he grows, and develops a larger habitation for $\mathrm{Mr}$ Crab who thus does not develop the longing for periodic flittings into a new house. If my theory about the nutritive persons deriving food from the scraps of Mr Crab's meals requires support his cousin adamsia is prepared to furnish it, for his mouth and tentacles are on the under side and close up to the opening left for $\mathrm{Mr}$ Crab's head. The tentacles are developed to run right asross so that no scraps escaping from the crab may be wasted in the vasty deep.

This brings us to the end of our subject for to-night, but before concluding I would like to mention briefly one or two of the many animals I have found lying side by side with the hydroids.

The worms we must pass over however interesting they may be, for they would take up too much time.

Foraminifera are found in various stages of growth, and as a rule living when taken from below low water mark. To see these when fully extended is a sight never to be forgotteu. I will not enlarge upon these, but merely emphasise the rule I gave before, viz., allow as little time as possible to elapse between collecting and examining.

The larger species like the bottle-brush are the favourite haunts of a certain class of shrimps. Regarding these shrimps, zoologists are at 
present divided, but I should not be at all surprised if it should be proved that when these shrimps develop to their full growth they form a considerable item in the list of foods suitable for fish sustenance.

Another of the crustacea I would mention is caprella. There are two forms I have found on Antennularia, viz, the smooth and the spiny. They clasp the stem with the three pairs of posterior claws, and the head and fore limbs are bent back away from the stem in search of food. What I would like to direct your attention to, if you should follow these up, is the two pairs of breathing apparatus attached to the sides of the body. This departure from the true crustacean type is worthy of all due consideration.

Numerous varieties of minute encrusting seaweed are also to be seen; but I am afraid I have already trespassed too far on your forbearance. Suffice it to say, that if any member of the Field Club should take up this subject as a special study I will be most glad, for I think some account of the hydroids found around the Buchan coasts would be no mean addition to the Transactions of the Buchan Field Club. 





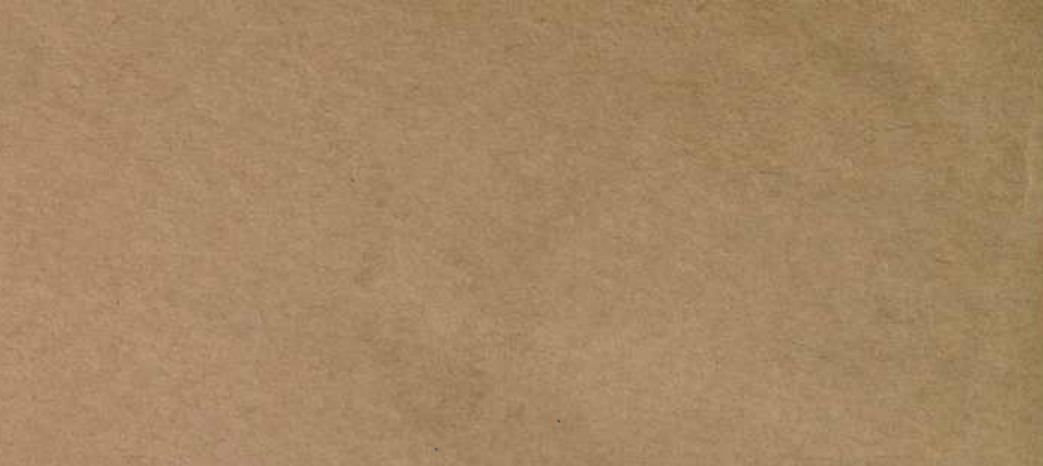





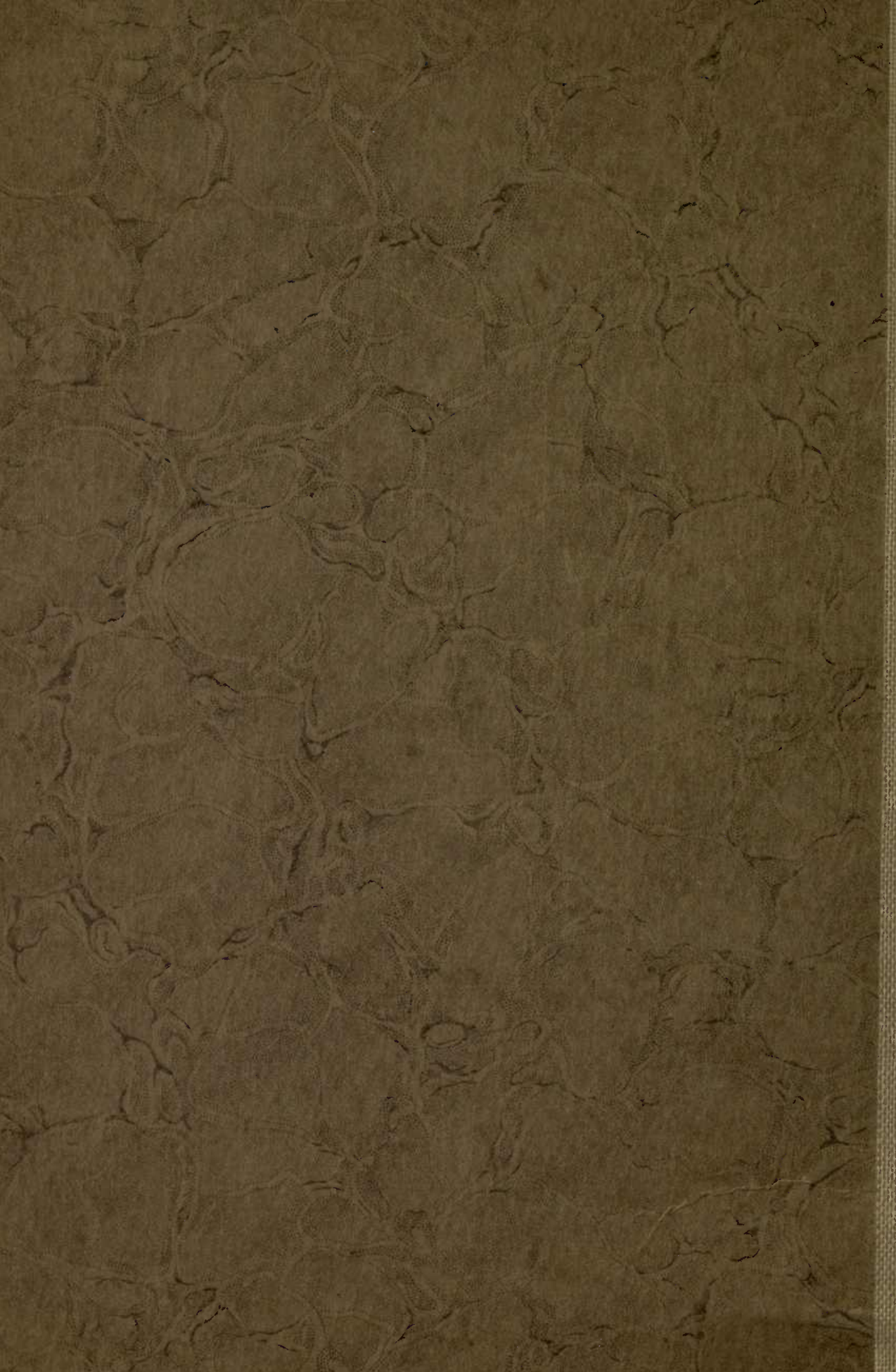

